\title{
Does Appearance of the Migrants Change Citizens Perception of the Public Space? Case Study of Disturbed Sustainability, Belgrade, Serbia
}

\author{
Czy pojawienie się migrantów zmienia postrzeganie \\ przestrzeni publicznej przez obywateli? \\ Przypadek naruszonej zrównoważoności, Belgrad, Serbia
}

\author{
Nataša Danilović Hristić ${ }^{*}$ Nebojša Stefanović ${ }^{\star \star}$ \\ Institute of Architecture and Urban \& Spatial Planning of Serbia \\ Bulevar Kralja Aleksandra73/II, Belgrade, Serbia \\ E-mails:*natasadh@iaus.ac.rs,**nebojsa@iaus.ac.rs
}

\begin{abstract}
The migrant crisis that hit Europe in 2015 established Belgrade as one of transit cities on the route along which they travel to the final destination. A large number of migrants, no matter of reason for leaving homeland (war, economy, climate change consequences), mostly men travelling alone, prefer to stay in the central urban parks or squares. The result was change of personal feeling of safety of citizens and intensive monitoring by local police, but some other examples gave us a different focus, when the spontaneously formed refugee camp, with tents set up in parks, became a temporary assistance centre and meeting point for citizens and refugees.
\end{abstract}

Key words: public space, safety, citizens, migrants

\section{Streszczenie}

Podczas kryzysu migracyjny, który dotknął Europę w 2015 r., Belgrad stał się jednym z miast tranzytowych na trasie, którą migranci podróżują do miejsca docelowego. Duża liczba migrantów, bez względu na powód opuszczenia ojczyzny (wojna, gospodarka, konsekwencje zmiany klimatu), głównie mężczyźni podróżujący samotnie, decydowała się zatrzymać w parkach miejskich lub na placach. Rezultatem była zmiana osobistego poczucia bezpieczeństwa obywateli i intensywne monitorowanie przez lokalną policję. Bywało jednak także tak, że spontanicznie tworzony obóz dla uchodźców z namiotami ustawionymi w parkach stawał się tymczasowym centrum pomocy i miejscem spotkań obywateli i uchodźców.

Słowa kluczowe: przestrzeń publiczna, bezpieczeństwo, obywatele, migranci

\section{Introduction}

The issue of urban safety became globally the main aspect of urban life quality and sustainability (Rydzewski, 2019), measurable not only by crime rates but by personal feeling and perception of space characteristics and other users. On other hand, public urban space is a mirror of the society, physical expression of its structure and mentality. In international theoretical discussions and practical researches, the result is that people feel safe in the areas that are alive and frequented, well illuminated or in some manner monitored at night (Ortiz de Urbina Gimeno, 2008) and they feel insecure in the spacious spaces without enough visitors or in the presence of risky groups (Schneider, 2007). The feeling of insecurity is equally caused both by spatial elements and by the presence of 'unwanted persons', and the majority of citizens believe that there is interdependence, i.e. the spaces that are under-equipped and used to attract offenders or other persons who inspire fear (listed as: homeless, alcoholics, drug addicts, etc.), which makes the space dangerous and undesirable (Whitzman, 2008). The fear of strange 
and unknown, encompassing space and persons using it, is common feeling in everyday urban life and movement of citizens (Mitchell, Sparke, 2018). The presence of, by appearance, attitude and habits, different people in our local spaces, in combination with prejudice, causes anxiety and annoy, leads to avoiding and temporarily abandonment of locations. The list of persons who inspire fear is amended by migrants, especially if they are male and gathered in groups, or acting inappropriately to social standards of hosts (Saad, Essex, 2018). Concerns about occupying public spaces is just a part of broader picture, because citizens prevalently care about consequences on sustainability of their social system economic, political and heath domain (Arsenijević, et al., 2017). The reasons for migration may diverse, because of war clashes, seeking for a job opportunity, any disturb of sustainability in environment (Krajewski, 2017) and may cause overflow effect in host ambience, depending on intension. Deviation of traditional use of public spaces appeared in all cities on migrant's exodus route elsewhere in Europe (Bertolia et al., 2016), therefore studies and comparisons of this extreme circumstance is valuable (Tsavdaroglou, 2018). For instance, refugees arriving into Athens in 2015, started to settle in the city's central public park, Pedion Areos until accommodation was available elsewhere (Afouxenidis et al., 2017). Welcoming migrants with dignity, social integration and preventing discriminatory attitudes should be goal overall (Cities \& Migration, 2017). The central and historical core area of Belgrade with a network of commercial and pedestrian streets, squares and urban parks (Figure 1), than public greenery inside residential zones, as picnic and recreational sites by the rivers, are examples of frequently used public spaces. The citizens have a long tradition of enjoying and sharing public space, spending free and leisure time or participate in different events (concerts, celebrations, sports or political protests). Consequently, in the stated goals and packages of measures proposed by Sustainable and Integrated Urban Development Strategy of Serbia 2030 , is improvement of quality, accessibility and safety of urban spaces. The conclusions of one of conducted surveys $(\mathrm{Gehl}, 2008)$ provided opinion on developed culture of urban life in open spaces, according to the climate zone and mentality of people and generally evaluated positively consequential effects on the city vitality. Also gave a recommendation to keep attitude, to continue to develop and design urban public spaces, create extra connections in matrix and new attractions in order to avoid leaving of visitors to semi-public spaces as enclosed shopping malls. The level of social interactions between the people is very high and contacts are diverse. An important characteristic of the public spaces is their integration and incorporation in the network system that allows for unrestricted movement and use. If any element of this network is considered by the users to be inadequate, unsafe or undesirable, it would result in its avoidance and exclusion. In line of identification and diagnosis of problems, it is important to identify whether it concerned just a poor spatial organization, neglect and failure to maintain the space, the more profound sociological problem of settlement or a combination of all these problems (Danilović Hristić, 2013). There is possibility for unpleasant events and acts of crime and violence to happen exactly where the environment provides them the opportunity by its nature (e.g. neglected, isolated, badly laid, dark and similar spaces). The applied measures of prevention (Kulach, 2008), could contribute to more comfortable urban public space usage and the fear of urban structure could be reduced as the fear of possible risky activities and incidents. With small additional investment, huge benefit can be achieved which registers in the more intensive use of urban public spaces but the surrounding functions as well, and resulting in the pleasure of the users, increased mobility, feeling of a higher level of security and belonging to the society and economic profit. These measures are less imposing and by far more agreeable than institutional controls of the space by surveillance of law-enforcements (uniformed officers, video cameras and so like).

\section{Methodology - The studies conducted from the aspect of safety}

Methodology used in paper consist of a case study with brief content analysis and comparison of survey data from various periods, before, during and after migration waves. Available data were usually unclassified or uneven in its structure and level of detail. For their direct use was necessary to take account of their accuracy, precision and mode of interpretation. Research is based on a theoretical framework which is multidisciplinary, not just with urban planning as a focus, but criminology and social science. Interaction of knowledge coming from different scientific disciplines creates the basis necessary for the understanding of this contemporary urban problem.

The specific studies on subject of urban safety and security, including personal feeling of the users of urban public spaces, were not conducted until recently on the territory of Belgrade with about 1,7 million habitants. The reason for that was long term consideration that the city is generally safe with an average crime rate. Belgrade was organizer of various international events and very hospitable, but, difficulties during 90'ties, caused by political and economic situation, and degradation of social norms and standards, have introduced some changes. It was not until the middle of the last decade that studies were conducted on this topic from the viewpoint of sociology and criminology, but never from the aspect of urban planning (Danilović Hristić, 2012). One of the basic studies was survey about perception 


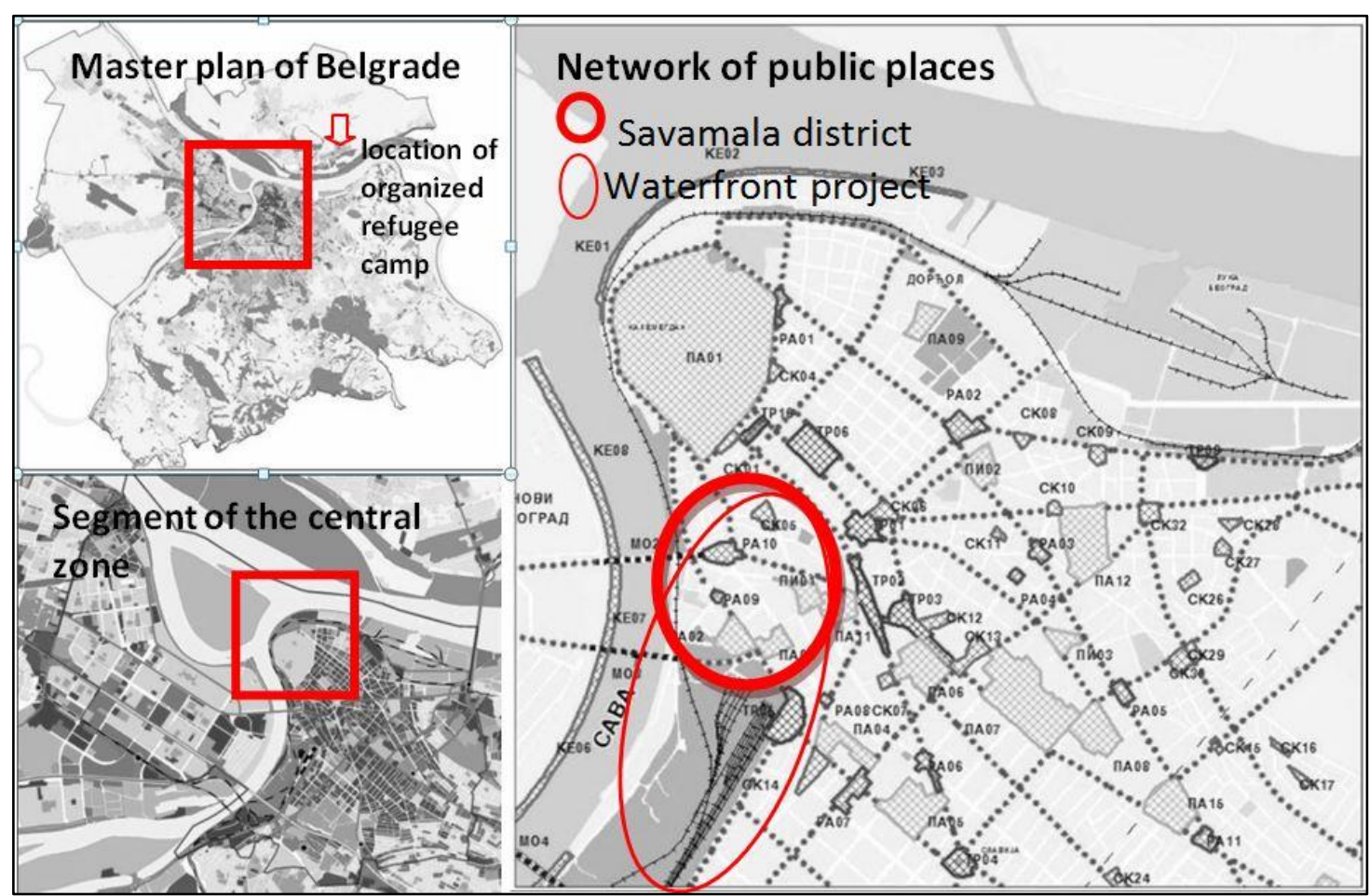

Figure 1. Location map: Master plan of Belgrade, position of central zone and network of main public spaces, including Savamala area and Waterfront development

and issues of neighborhood safety in three city areas, with participation of children and their parents, prepared by The Institute for Sociological Researches of the Faculty of Philosophy in Belgrade in 2003-2004. The most frequent risk sources are the presence of drug addiction in the spaces planned for the stay and play of children, un illuminated space and disorder in the space, suspicious unknown individuals and bullying (Tomanović, 2006). The second research about citizens attitude about urban safety, which results can be used for comparison with more resent data, is a study of Institute for Political Studies, Center for Security Studies and Terrorism Research, conducted successively in 2004, 2007 and 2008. In addition, it is possible to consult certain and occasional publications of the Institute for Criminological and Sociological Researches, OSCE Mission to Serbia and UN-HABITAT. The information about the attitude of the citizens of Serbia towards safety is a result of the public opinion poll on police reform in Serbia which was conducted by OSCE and IPSOS Strategic Marketing. The survey was conducted in two phases (in November 2008 and October 2009); on the total of 2990 respondents, aged over 18 and by face to face method. The question asked Which problems do you think present the greatest threat to the security of the citizens in Serbia? resulted with violence in public places as an answer taking the fifth place, with an increase of concerned citizens from $3 \%$ in 2008 to $9 \%$ in 2009. Responses like drug abuse (in the first place), crime (generally speaking, elsewhere), violence (in the fourth place) and minor offenses (in the sixth) are not negligible either, since they are all in some way associated with the level of safety in public places.

\section{Results - Relevance between spatial and social component of safety}

The research conducted in 2007-2008 by the team of Urban Planning Institute of Belgrade gave for the first time strong spatial aspect to the topic with conclusions and recommendations for better and safer urban public spaces. Based on the data and information available to the Ministry of Interior Affairs of the Republic of Serbia, MIARS - Secretariat of Belgrade and non-government organizations (SOS telephones, legal aid, trauma center, safe houses, etc.), an impression can be obtained on the cases of violence in urban public spaces. Narrowing down the analysis of the data to one specific society group - women, according to the traditional understanding as a sensitive and easily vulnerable population groups, which at the same time is rather active and mobile, and in Belgrade makes a significant proportion of the population (according to the census from 2011, about $53 \%$ of the capital population are women). Based on data obtained from the MIARS a review of criminal acts which were committed exclusively in public areas against women on the territory of ten city municipalities of Belgrade was created. For example, in the period from 2000 to 2005, when 2135 cases of robbery of women were recorded and also the declining trend of this type of crime was observed (Danilović Hristić 2008, 2012). 


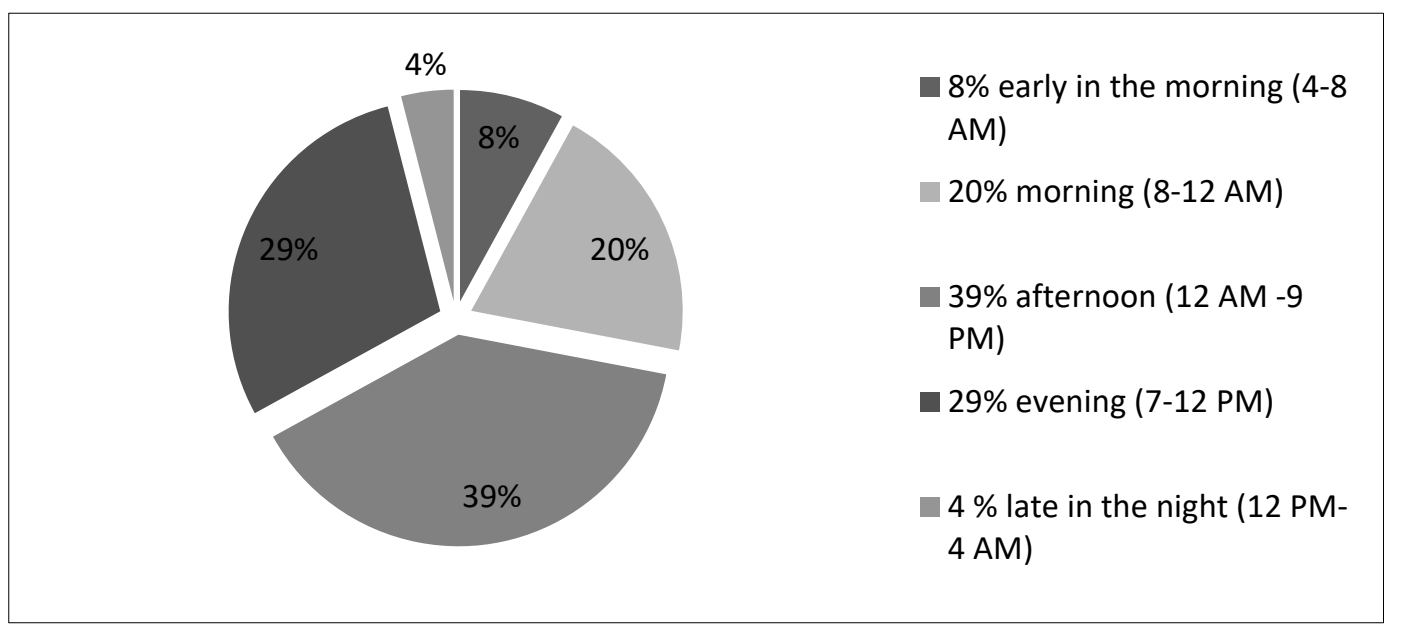

Figure 2. The most frequent period of mobility in the open public spaces, Source: Danilović, 2008.

The users' perception of space and its safety was based on the survey questions classified in three groups:

- personal information on the respondents as well as their daily habits,

- individual perceptions, feelings and experience about urban places, mobility and safety,

- $\quad$ suggestions and proposals - law-enforcement, measures for improvement.

The goal was to determine personal feeling of safety in public spaces, as well as information gathering for producing a graphical outcome of black spots or stretches, meaning more vulnerable or exposed to danger places. Thus marked locations as opposed to a network of spaces that have been evaluated as safe, provide the signal at which place it is necessary to implement any of the technical measures of prevention or to reinforce police supervision.

In order to obtain as clear indicators as possible, the survey was anonymous and was distributed to various categories of population, i.e. it was ensured to include the participation of both sexes, various generations, certain threatened and minority groups, as well as foreign citizens currently living and working in Belgrade (Danilović Hristić, 2012). The obtained result was that the majority of citizens stay in the public spaces in the afternoon, after working hour or school time, between noon and 9PM, and during the most active part of the day, from 8AM-12PM (Figure 2), with $88 \%$ of stays outside the place of residence. The most of the respondents take mobility in the public space as leisure activity, like walking the dog in the early morning, going to market or window-shopping on weekends, stay in the park in the afternoon with children, walking downtown in the evening, meeting with friends, going to an outdoor event, but not going to work or college. The result indicates to South European's mentality, that consider frequent and gladly use of public space as everyday lifestyle, for all generations, even in late hours on the working day.
The mobility of the citizens, i.e. the undisturbed feeling of freedom and security in using urban public spaces is of great importance (Holland, 2007). 'When answering the question whether the respondents avoided certain parts of the city, some settlements or parts of the space in fearfor their own safety, half of the respondents opted for positive reply. Generally, it primarily concerned vast park spaces in which citizens did notfeel comfortable when it got dark, then the areas primarily intended for traffic (highway loops around highways, the area around the railway and bus stations, bridges, underground passages) and also the areas with a great circulation of pedestrians where due to crowds some minor criminal act such as theft is possible. It is quite interesting that approximately the same number of respondents stated spatial and social problems as crucial for avoiding certain parts of the city (Figure 3).The relation between these two aspects is obvious, i.e. dark and unarranged spaces, according to the understanding of the citizens, automatically attract the individuals of deviant behaviour (according to the survey's quotes: 'homeless persons, alcoholics, junkies, bullies') and present potential danger for all the rest. As regards the question what the citizens were afraid of, i.e. what prevented or restrained them to stay in certain urban public spaces during certain period of day and night, mostly quoted answers indicated to the combination of spatial and social problems, such as insufficiently illuminated spaces, desertedness i.e. absence of other users, or presence of persons who one can expect offences and violent attacks from. The feeling of greater security when in group compared to when the individuals find themselves in urban public spaces does not significantly differ, 53\% versus 45\%" (Danilović Hristić 2012). The conclusion of this survey dating 2008, was that the residents still feel relatively safe in urban public space of Belgrade. 


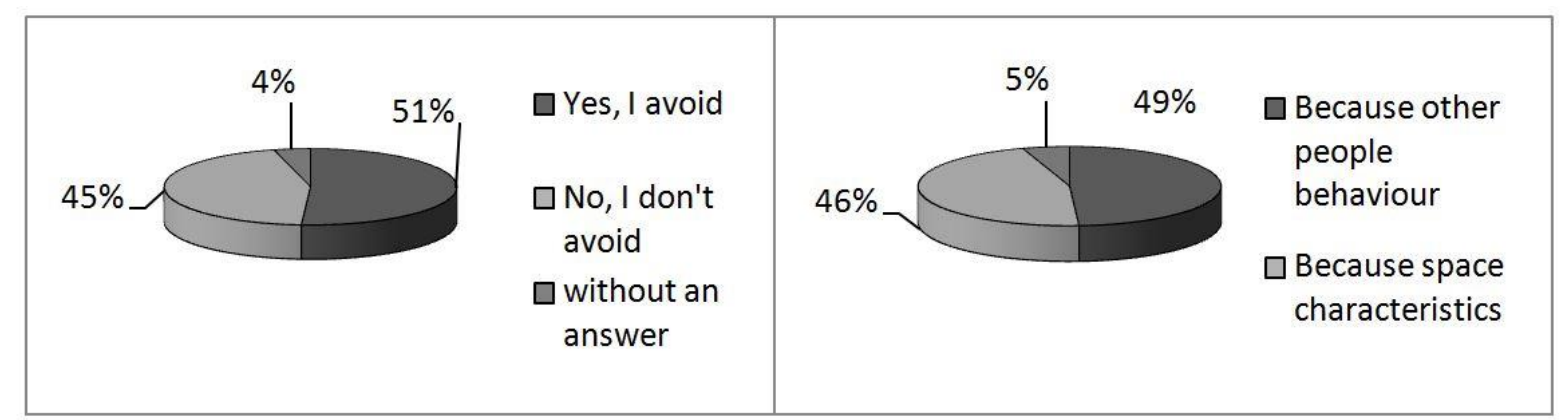

Figure 3. Do you avoid some urban public spaces because of fear for your personal safety (left), and why (right)? Source: Danilović, 2012.

\section{Discussion - Arrival of the migrants and tempo- rary capture of some public areas}

In the migrant crisis that hit Europe in summer 2015, the EU member states, as well as other countries on the migrant route (Figure 4), to the desired destination, respond in a different way to the inflow of migrants, either by receiving them, sending them to other countries or closing their borders to migrants. The crisis has not yet got its epilogue, i.e. all consequences from the immigrant inflows for the cities on the migrant route cannot be perceived in the moment, but by the time flow (Danilović Hristić et al., 2018). It is inevitable to reflect on the reality of the future social integration and inclusion, or segregation, as well as on the cultural differences, xenophobia, fear of terrorism (Danilović Hrstić, 2016), safety, mutual understanding and ignorance, as well as the key issues of the economic limit. These issues will also spill over into the field of urban planning, and it should be addressed in a holistic way and from all apsects of integrated urban development to ensure social, economic and environmental urban sustainability (Murillo, 2017). The Republic of Serbia has been facing a rising number of persons seeking asylum since 2008 (Krstić, 2012). The migratory trends culminated in 2015 and have undoubtedly pointed out an accelerated arrival of migrants and the need to timely carry out necessary preparations for the humanitarian reception. The number of migrants accommodated in 18 Serbian facilities varied due to the new reception centres opened meanwhile and the change of the migrant's route. By the location and significans for newcomers the cities on the route can be divided to three categories: cities of migrant arrivals (ports, border places, etc. on the South of Europe), transit cities with different period of stay (in case of Serbia), and the cities of the desired final destination (North of Europe's continent, mostly Germany or Scandinavian countries). On the places of their arrival, centres close to state borders, the migrants are registered and provided with the first assistance, necessary health care, important information about the legal options (APC/CZA 2016) and the residence permit in Serbia or the Schengen countries, with administrative support for regulating their status (Law on Asylum, 2007; Law on Foreign Citizens, 2008; Law on Migration Management, 2012; Law on Refugees, 2010), and providing transportation options for continuing their journey (Knežić, 2011). The organized temporary accommodation is most frequently located on the periphery of cities, in the form of prefabricated facilities suited for the needs of migrants (tents, barrack, etc.), or within the reconstructed buildings adapted to this purpose (warehouse halls no longer in use, sports facilities, schools, military barracks, etc.). The length of stay in these facilities varies; priority is given to the families with children and during the cold periods of the year. However, a large number of migrants, mostly men travelling alone or in smaller groups, refuse an organized and institutional accommodation either because they do not want to register themselves or prefer to stay in the central urban areas close to the central bus and railway stations and nearby the border crossings. Their stay in the public spaces, mostly in the surrounding parks or squares, or in the abandoned buildings, not causing just sanitation problems, but distrust and discomfort of the local population too (Danilović Hristić et al., 2018), particularly due to the frequent incidents, both internal clashes and the inappropriate behaviour resulting from the cultural differences and psychological trauma brought from the war-affected countries (Mekdjian, 2017). The cities are coping with the growing security problems both in public spaces and abandoned buildings by fencing those public spaces, intensive monitoring by local police, but also with the utilities and sanitation problems. It became obviously that some urban public places are captured by migrants and simultaneously avoided or abandoned by regular visitors.

\section{The mild change of the attitude}

Facing the refugee waves of Serbian population in the late 20 th and early 21 st century from former $\mathrm{Yu}$ goslavia, Serbia has acquired experience in receiving and quickly accommodating the newcomers, while the society itself has developed a certain degree of understanding and solidarity with people who were forced to flee from their homes. But situations about 


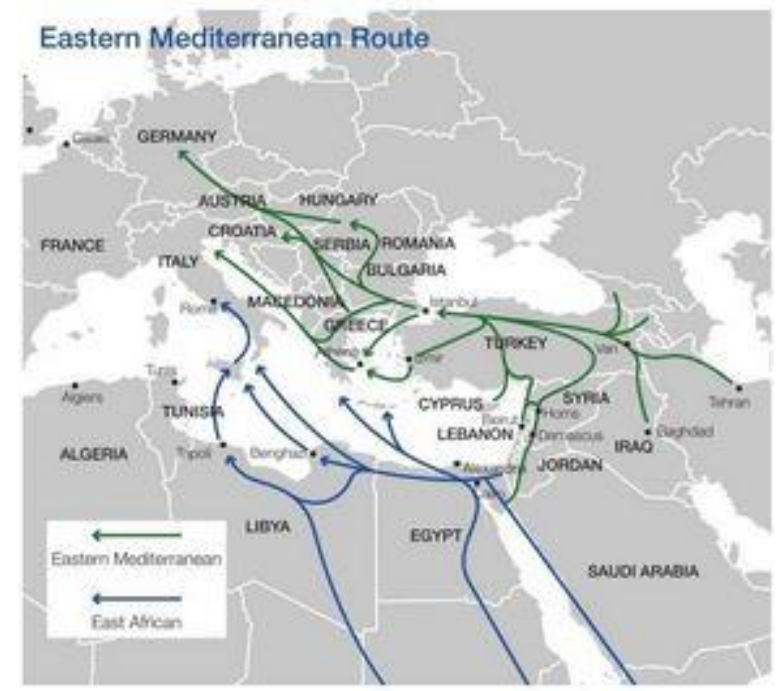

Figure 4: Eastern Mediterranean Route. Source: 'Migration and Its Impact on Cities, World Economic Forum, 2017, page 23 .

the refugees and migrants were completely different, the first ones were part of own nation seeking for new home (same people, language, religion, usually with some relatives living in Serbia), the second group were strangers in transit. It is difficult to estimate the realistic relationship between citizens and migrants (Bobić, 2013) because people have different opinion based on personal experiences and potential close contact, depending from the size of urban settlement, proximity to the route and visibility of the groups of migrants, or existence of the centre for acceptance and accommodation in their neighbourhood but on prejudice.

In 2014 (CeSID \& UNHCR, 2014) and 2016 (Ninamedia Research, 2016) the researches The attitude of the citizens of the Republic of Serbia towards asylum seekers gave some results about perception of citizens regarding the migrants. About $68 \%$ of participant in inquiry said that there is a significant difference between refugee and migrant/asylum seeker. The question about the location of temporary centres close to the residential areas gave result that $30 \%$ is opponent and $24 \%$ will be against if there is some other solution. As a reasons for such attitude $25 \%$ stated the tension and fear for personal and members of family security (specially harassment and rape), $8 \%$ cultural habits and religious differences, $10 \%$ because possibility for increasing the crime rate, and one of the reasons is the fear of sanitation problem and contagious diseases, all typical negative ethnical or safety stereotypes and prejudice (Figure 5). In the same time about $48 \%$ feel compassion, $24 \%$ express their sadness about situation of migrants and about $8 \%$ identify fear. It seems that citizens in generally have fellow feeling about those who migrate, especially for families with children and women, but in the same time perceive unsafe and they are not disposed to have male migrants (alone or in groups) in close surrounding or to share same urban space with.
Usual comments are: We have problems with them, but we think it is necessary to help this people. So if you can find some compromise... (addressing to the Authorities); I regret everything that's going on, it's not easy for them either, but they do not belong here; Great that are removed away from the city centre, because disturbing, violation and harassment they often make.' In the matter of avoiding urban public spaces, the opinion of the citizens stayed in the same scope, just the migrants became one of unwanted groups, beside previously mentioned presence of various local offenders or homeless. According to this, citizens of Belgrade, Serbia, in their opinions and feelings do not differ much from other citizens in EU countries (Kyriakides, 2017; Vallaster, 2017). Although they understand situation and needs of migrants (Mantovan, 2018), basically they are against usurpation of public spaces and appeal for quick and responsible act of Authorities, namely police, Ministry for Social Affairs and Commissariat for Refugees.

On the other hand, one example of the spontaneously formed humanitarian centre is the central $\mathrm{Sa}$ vamala district in Belgrade. This is historic but neglected area close to the railway and bus stations, where gentrification started spontaneously and continued with large scale project Belgrade Waterfront. Groups of refugees used central public spaces in Savamala area and derelict buildings to sleep over, create networks, obtain aid and wait for transport or smugglers (Obradovic-Wochnik, 2018). Different types of institutions, NGOs and citizens participated in forming a temporary assistance centre, with tents set up in parks, during largest wave of migrants in summer 2015. The citizens of Belgrade voluntary provided different kind of goods, mostly food and warm clothes, toys for children, also. They offered professional help too, participating as doctors during health controls and distribution of the medicines, advocates came forward with legal help and advices, teachers were giving to children educational and amusement programs, actors and musicians performed plays and concerts. The community proved itself as human and in good will to help as much as can, with great hospitality and sympathy for migrants, without any fear. But when the most of them (specially families, mostly from Syria) left the location, travelling to the final destinations and only male economic migrants (from Afghanistan, Pakistan, etc.), that have difficulties to get access to EU countries, stayed in park or abandoned structures around railway station and industrial zone, already planned for urban reconstruction, the situation changed (Figure 6). The residents of neighboring urban tissue expressed the disagreement, because the personal feeling of safety became seriously jeopardized. It started with complains about noise, garbage and continued with harassment of women and protest of parents of children from nearby primary school. On behalf several massive fights and street 


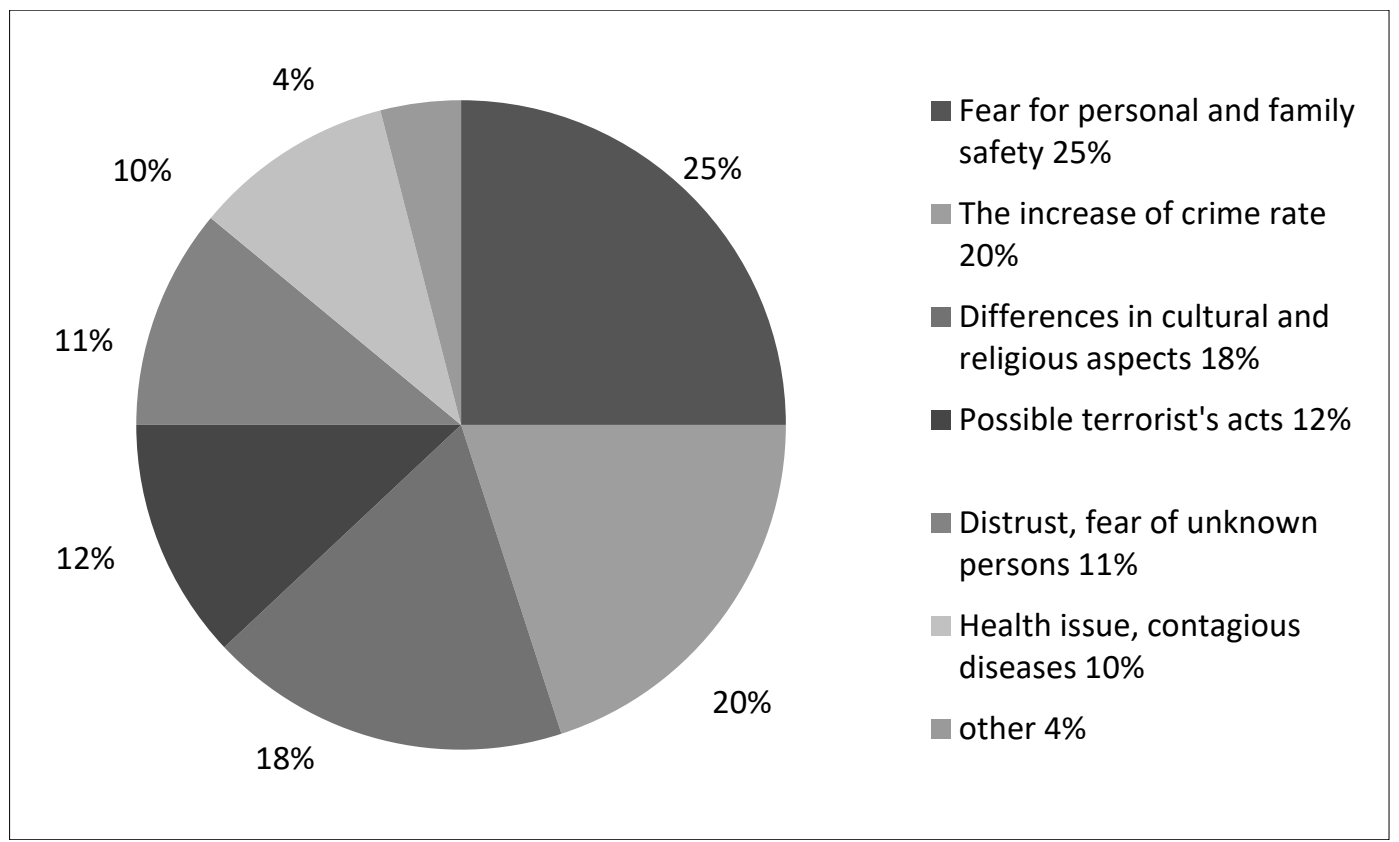

Figure 5. Personal feeling of citizens about sharing public urban space with migrants (by the Authors, based on several polls data)

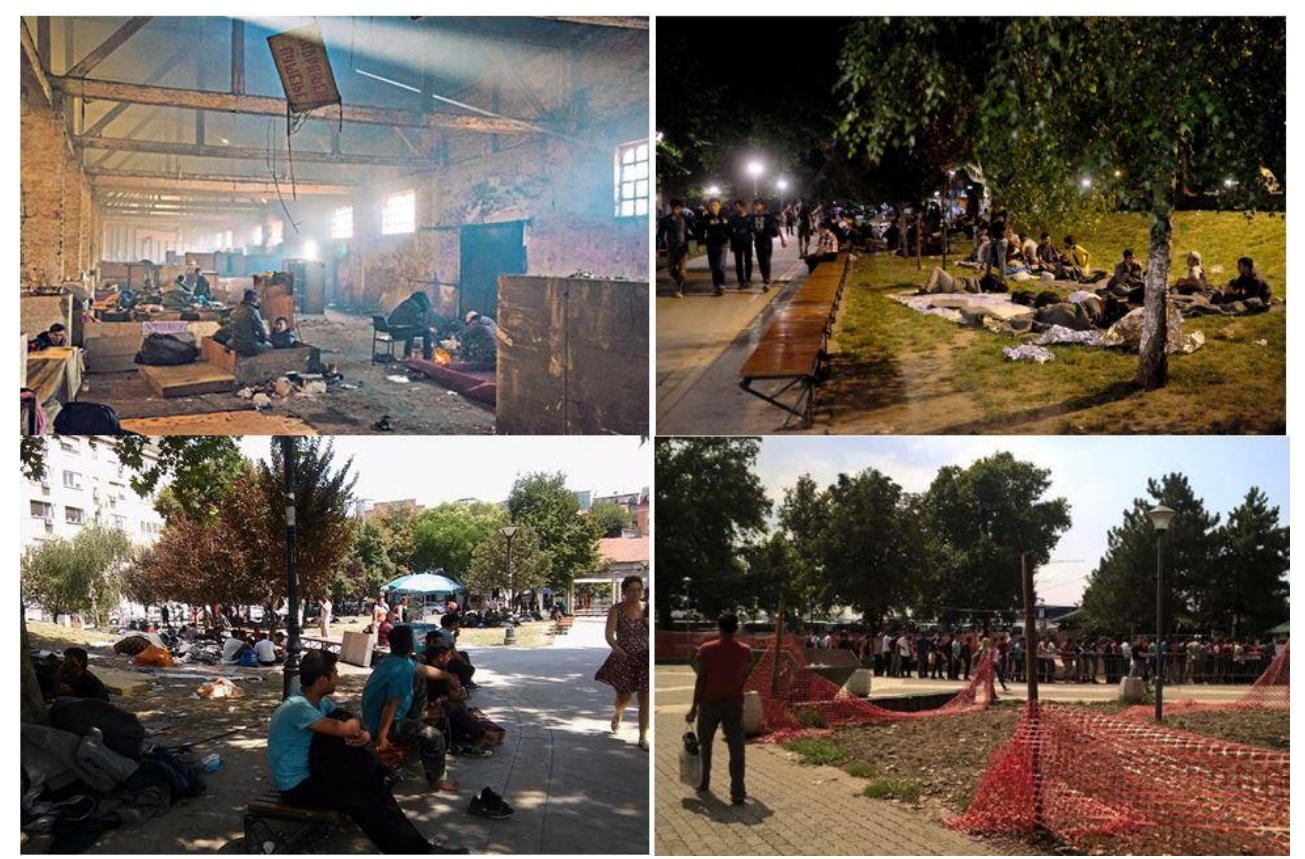

Figure 6. Savamala area of Belgrade in 2015/2016: occupancy of abandoned storage building and park (up and left down), food queues for the Refugee Aid Serbia meals and orange fence preventing the use of the park (right down). Sources: media via internet (www.blic.rs, www.telegraf.rs), Obradovic-Wochnik, 2018.

clashes between groups of migrants and murder of the prostitute (in period 2016-2017), local police in cooperation with refugee and migrant program had to disperse this area and enhance patrolling and surveillance. It seems that Authorities tolerated the presence of refugees in public spaces during the height of the media attention in 2015 , which very quickly shifted to concealment as the Belgrade Waterfront development got under way, displacing towards camps started (Obradovic-Wochnik, 2018).
The situation slightly changed, according to the survey results from this and neighbouring area collected in spring 2017, when a total number of 311 people participated, 182 female and 129 male, 45 residents and 266 visitors or tourists, citizens, aged mostly from 15-25 and 26-41. Results from the questionnaire, for the topic of quality of space, namely safety, is average grade (in scale 1-5) 3,93 given by residents and 3,46 evaluated by visitors (Maric, Djukic, 2018). The Balkan migration route is still active, alt- 
hough the number of migrants was stagnating. There have been still between 4,000 and 6,000 people with prolonged stay for up to 4-6 weeks in average in Serbia, mostly because the movement of migrants through Croatia and Hungary became difficult. Just for comparison, in 2015 about 7,000 migrants crossed the country border each day. Although smuggling and illegal movement is still actual these estimates are based on the data about migrants reporting themselves to the official centers. Now days, migrants are situated in refugee camp in Krnjaca, far away from city center and just occasionally can be noticed, waking through city core.

\section{Conclusion}

Using open and public urban spaces in society with Mediterranean mentality is in manner of often and familiarly. If there is any fear about security and personal safety, it is connected equally with the shape and appearance of the space, as with hazardous persons how reside it. However, public spaces are subject to various explicit and implicit rules, spatial and other kind regulations and surveillance practices aimed at preventing specific groups of people from behaviour badly and violate the others. The arrival of migrants to Belgrade and other Serbian cities, on their route from South to North and West of Europe, made some mild change in the attitude of citizens about spaces they temporary captured. The doubts and fears are often in the background of the openness in expressed commitment to accept migrants in our societies and surrounding. There are many reasons for this uncomfortable feeling of the citizens, that bypass urban public spaces captured by newcomers. In one part there is realistic fear caused by negative experience, witnessing different acts of harassments or violence. This, usually rear and lonely cases get an excessive attention in media and rapidly increase fear and chance public opinion about the issue. On other hand, the common and natural fear of unknown and strange may be the main cause for stereotypes and prejudice. Citizens expressed their sympathy for families, children and elderly, but tension about groups of young males. There were evidence of avoiding the public urban space next to railway and main bus station in Belgrade during migrant crisis in 2015 , and sometime after the main wave, while some of migrants, mostly single male stayed illegally in open public spaces (during summer period) or abandoned structures (in winter days). Because that authorities had to disperse this area, but it alongside pushed forward the large scale program of the urban reconstruction.

Taking Belgrade's public places as a case study, comparing data collected about urban safety, in range of 10 years, Authors argue that extreme situation like migrant crisis in 2015 with influence of strange elements, can cause disorder in everyday habits. The prevention measures, enforced in accus- tomed and regular situations, does not necessary suite and apply in this case. The spatial characteristics of urban surrounding was not primary, actually were prerequisite only for positioning of migrant groups, but not evaluated previously by citizens as critically deterrent. Sympathy for families in need, was strong and provoked collecting of humanitarian aid, gathering and social inclusion. Lately, the presence of less eligible and by media emphasized problem, led to fear of unknown and demand for resolving the situation. Closing the area due to the beginning of urban renewal process was excuses to move rest of the migrants to organized camps, far away the city centre. The conclusion is the attitude of the citizens about urban safety issue can be easily changed during the time to more positive or negative, not just by rising the question of particular topic, application of general or more detailed urban design and other surveillance measures in public space, but periodically because global and regional circumstances and impacts, beyond local influences.

\section{Acknowledgements}

The paper is a result of research conducted as part of the scientific projects: Spatial, environmental, energy and social aspects of developing settlements and climate change - mutual impacts (TR 36035); Sustainable spatial development of the Danube region in Serbia (TR 36036); and The role and implementation of the National spatial plan and regional development documents in renewal of strategic research, thinking and governance in Serbia (III 47014), financed by the Ministry of Education, Science and Technological Development of the Republic of Serbia in the period 2011-2018.

\section{References}

1. AFOUXENIDIS A., PETROU M., KANDYLIS G., TRAMOUNTANIS A., GIANNAKI D., 2017, Dealing with a humanitarian crisis: Refugees on the Eastern EU border of the island of Lesvos, in: Journal of Applied Security Research, 12(1), p. 7-39. DOI:10.1080/19361610.2017.1228023

2. APC/CZA - Asylum Protection Centre, Belgrade, Serbia, The European Union EIDHR Programme for Serbia, 2015, Migrant Info Flayer, http://www.apccza.org.

3. ARSENIJEVIĆ J. et al., 2017, A crisis of protection and safe passage: violence experienced by migrants/refugees travelling along the Western Balkan corridor to Northern Europe, in: Conflict and Health, 11(6). DOI: 10.1186/s13031-017-0107-z.

4. BERTOLIA S., BRUCKERB H., FERNANDEZHUERTAS MORAGAC J., 2016, The European crisis and migration to Germany, in: Regional Science and Urban Economics, 60, p. 61-72.

5. BOBIĆ M., 2013, Imigracija u Srbiji: stanje i perspektive, tolerancija i integracija /Immigration in Serbia: the situation and perspectives, tolerance and integration, in: Demografija, X, p. 99-115. 
6. CeSID \& UNHCR, 2014, Stav građana Republike Srbije prema tražiocima azila, http://www.unhcr. rs/media/CeSIDUNHCR201014FINAL.pdf

7. DANILOVIĆ HRISTIĆ N. (ed.), 2008, Sigurniji javni prostori, studija o bezbednosti javnih gradskih prostora u Beogradu, Urbanistički zavod Beograda i Misija OEBS u Srbiji, Odeljenje za demokratizaciju, Demsec projekat.

8. DANILOVIĆ HRISTIĆ N., 2012, Urban safety of the public spaces in Belgrade, Serbia?, in: Re-mixing the city towards sustainability and resilience. Proceedings of $17^{\text {th }}$ International Conference on Urban Planning and Regional Development in the Information Society REAL CORP 2012, eds. Schrenk, M., Popovich V., Zeile, P. and Elisei, P., Schwechat-Rannersdorf: Kompetenzzentrum für Stadtplanung und Regionalentwicklung, Austria, p. 1007-1016.

9. DANILOVIĆ HRISTIĆ N., 2013, Bezbednost urbanih prostora, Orion Art., Beograd.

10. DANILOVIĆ HRISTIĆ N., 2016, Keynote Speaker: Languish After Safety in the Urban Life, in: Conference Proceedings, Fourth International Conference and Exhibition, On Architecture: Scale of Design From Micro to Macro, Belgrade: STRAND, 1-5 December 2016, p. 43-51, http://www.strand.rs/micro macro/.

11. DANILOVIĆ HRISTIĆ N., GLIGORIJEVIĆ Ž., STEFANOVIĆ N., 2018, Possible impact of migrant crisis on the concept of urban planning, in: Conference Proceedings 'Places an Technologies 2018', University of Belgrade Faculty of Architecture, Belgrade, Book of Conference Proceedings, p. 279-28.

12. DECLARATION OF THE CONFERENCE, 2017, Global Conference on 'Cities \& Migration', 16-17 November 2017, Mechelen, Belgium, https://unhabitat.org/gccm-cities-and-migration/.

13. EXPERT TEAM OF INSITUTE OF ARCHITECTURE AND URBAN \& SPATIAL PLANNNING OF SERBIA, 2018, Sustainable and Integrated Urban Development Strategy of Serbia 2030, Ministry of construction, transport and infrastructure of Serbia, GIZ/AMBERO, http://www.urbanlandmanagement. rs/? attachment_id=8111.

14. GEHL Architects, 2009, Urban Quality Consultants: Port of Belgrade, Strategies and Guidelines for a Harbour Development.

15. HOLLAND C., CLARK A., KATZ J., PEACE S., 2007, Social interactions in urban public places, Joseph Rowntree Foundation.

16. KNEŽIĆ B., VIDANOVIĆ V., 2011, Problems of asylum seekers in Serbia, in: Serbian Political Through, 34, p. 421-440.

17. KRAJEWSKI, P., 2017, Climatic Migrations - Consequences of Upsetting Environmental Balance and a of Flaws in Human Protection by International Law, in: Problemy Ekorozwoju/ Problems of Sustainable Development, 12(1), p.15-20.

18. KRSTIĆ I., 2012, Protecting the Rights of Migrants in the Republic of Serbia. Handbook for Civil Servants and Local Self-Government Officials, International Organization for Migration - Mission in Serbia, Project: 'Capacity Building of Institutions Involved in Migration Management and Reintegration of Returnees in the Republic of Serbia' (CBMM), Beograd.

19. KULACH J., WHISKIN N., MARKS E., 2008, Urban crime prevention policies in Europe: Towards a common culture?; European forum for urban safety, Safety \& Democracy.

20. KYRIAKIDES C., 2017, Words don't come easy: Al Jazeera's migrant-refugee distinction and the European culture of (mis)trust, in: Current Sociology, 65(7), p. 933-952.

21. LAW on Asylum Official Gazette of the Republic of Serbia, No. 109/2007.

22. LAW on Foreign Citizens, Official Gazette of the Republic of Serbia, No. 97/2008.

23. LAW on Migration Management, Official Gazette of the Republic of Serbia, No. 107/2012.

24. LAW on Refugees, Official Gazette of the Republic of Serbia, No. 18/92, 42/2002, 45/2005, 30/2010.

25. MANTOVAN C., 2018, They treat us like criminals': urban public spaces and ethnic discrimination in Italy, in: Patterns of Prejudice, 52(4), p. 338-354. DOI: $10.1080 / 0031322 X .2018 .1476209$

26. MARIC J., DJUKIC A., 2018, Connecting the Centre of Belgrade with the Danube and Sava Riverfronts to Increase Attractiveness, in: Periodica Polytechnica Architecture, 49(1), p. 23-28.

27. MEKDJIAN S., 2017, Urban artivism and migrations. Disrupting spatial and political segregation of migrants in European cities, in: Cities. DOI: 10.1016/j.cities.2017.05.008

28. MITCHELL K., SPARKE M., 2018, Hotspot geopolitics versus geosocial solidarity: Contending constructions of safe space for migrants in Europe, in: Environment and Planning D: Society and Space. DOI: $10.1177 / 0263775818793647$.

29. MURILLO, F., 2017, Migrants and rapid urbanization: A New Agenda for humanitarian and development urban planning? United Nations Expert Group Meeting on Sustainable Cities, Human Mobility and International Migration, Population Division, Department of Economic and Social Affairs, United Nations Secretariat, New York, 7-8 September 2017, UN/POP/EGM/2017/4.

30. NINAMEDIA RESEARCH, 2016, Stav građana Republike Srbije prema tražiocima azila, http://www.kirs.gov.rs.

31. OBRADOVIC-WOCHNIK J., 2018, Urban geographies of refugee journeys: Biopolitics, neoliberalism and contestation over public space in Belgrade, in: Political Geography, 67, p. 65-75. DOI: 10.1016/j.polgeo.2018.08.017Get.

32. ORTIZ DE URBINA GIMENO, I. \& PONCE SOLÉ, J. (coord.), 2008, Convivencia ciudadana, seguridad pública y urbanismo, Diez textos fundamentales del panorama internacional, Barcelona.

33. RYDZEWSKI P., 2019, Social Dimensions of Sustainable Development in International Public Opinion, in: Problemy Ekorozwoju/ Problems of Sustainable Development, 14(1) 1, p. 53-62.

34. SAAD H., ESSEX R., 2018, 'Arrival Cities: Final Dispatches' Final Report, 19 July 2018, Urbanact, http://urbact.eu/arrival-cities-final-report.

35. SCHNEIDER R. H., KITCHEN T., 2007, Crime Prevention and the Built Environment, Routledge, London.

36. TOMANOVIĆ S. (ed.), 2006, Društvo u previranjusociološke studije nekih aspekata društvene transformacije u Srbiji; Institut za sociološka istraživanja Filozofskog fakulteta u Beogradu.

37. TSAVDAROGLOU C., 2018, The newcomers' rights to the common space: The case of Athens during the 
refugee crisis ACME, in: An International Journal of Critical Geography, Preprint, p. 1-26.

38. VALLASTER C., WALLPACH VON S., ZENKER S., 2017, The interplay between urban policies and grassroots city brand co-creation and co-destruction during the refugee crisis: Insights from the city brand Munich (Germany), in: Cities, DOI: 10.1016/j.cities.2017.07.013.

39. WHITZMAN C., 2008, The Handboook of Community Safety, Gender and Violence Prevention - Practical Planning Tools, Earthscan,

London. 